Review

\title{
Innate Immune Mechanisms and Immunotherapy of Myeloid Malignancies
}

\author{
Sara Small 1,2, ${ }^{\text {, Yazan Numan }}{ }^{1,2}$ and Leonidas C. Platanias 1,2,3 \\ 1 Robert H. Lurie Comprehensive Cancer Center, Northwestern University, Chicago, IL 60611, USA; \\ yazan.numan@nm.org (Y.N.); 1-platanias@northwestern.edu (L.C.P.) \\ 2 Division of Hematology-Oncology, Department of Medicine, Feinberg School of Medicine, \\ Northwestern University, Chicago, IL 60611, USA \\ 3 Department of Medicine, Jesse Brown Veterans Affairs Medical Center, Chicago, IL 60612, USA \\ * Correspondence: sara.small@nm.org
}

check for updates

Citation: Small, S.; Numan, Y.;

Platanias, L.C. Innate Immune

Mechanisms and Immunotherapy of Myeloid Malignancies. Biomedicines 2021, 9, 1631. https://doi.org/ $10.3390 /$ biomedicines 9111631

Academic Editors: Carlos Del Fresno Sánchez and Eduardo Lopez-Collazo

Received: 12 October 2021

Accepted: 2 November 2021

Published: 6 November 2021

Publisher's Note: MDPI stays neutral with regard to jurisdictional claims in published maps and institutional affiliations.

Copyright: (c) 2021 by the authors. Licensee MDPI, Basel, Switzerland. This article is an open access article distributed under the terms and conditions of the Creative Commons Attribution (CC BY) license (https:// creativecommons.org/licenses/by/ $4.0 /$ )

\begin{abstract}
Similar to other cancers, myeloid malignancies are thought to subvert the immune system during their development. This subversion occurs via both malignant cell-autonomous and nonautonomous mechanisms and involves manipulation of the innate and adaptive immune systems. Multiple strategies are being studied to rejuvenate, redirect, or re-enforce the immune system in order to fight off myeloid malignancies. So far, the most successful strategies include interferon treatment and antibody-based therapies, though chimeric antigen receptor (CAR) cells and immune checkpoint inhibitors are also promising therapies. In this review, we discuss the inherent immune mechanisms of defense against myeloid malignancies, currently-approved agents, and agents under investigation. Overall, we evaluate the efficacy and potential of immuno-oncology in the treatment of myeloid malignancies.
\end{abstract}

Keywords: immunotherapy; AML; interferon; antibodies; myeloid malignancies; CAR-T

\section{Introduction}

The human immune system is capable of recognizing both foreign organisms and altered versions of self. This latter ability is a key mechanism that affords protection against neoplasms. Efficacious innate and adaptive immune systems are essential for this protection to succeed, whereas a dysfunctional immune system allows cancer cells to grow unhindered [1]. The recognition of the immune surveillance's role in preventing neoplastic growth and the discovery of immune system manipulation by malignant cells has led to the utilization of immune-targeted strategies in multiple malignancies. The launching of these novel strategies marked a new era of immuno-oncology in cancer therapeutics [2,3]. One strategy in immuno-oncology involves harnessing the power of the natural immune system to increase recognition and eradication of tumors; for example, by removing road blocks to this process with checkpoint inhibitors, ramping up the immune response with interferon treatment [4] or cancer vaccines, or directing immune cells to attack neoplastic cells with antibody therapy. Other strategies include introducing exogenous components of immunity such allogeneic hematopoietic stem cell transplants (allo-HSCT), donor lymphocyte infusions, and chimeric antigen receptor T-cell (CAR-T) cell therapy [5].

Allo-HSCT represents the oldest and most intensive form of immunotherapy against myeloid malignancies, to date, in the form of the graft-versus-leukemia effect [6,7]. For many patients, such as those with secondary AML, allo-HSCT represents the only modality of potential cure [8]. Other immune-related treatments, currently approved for myeloid malignancies, include the antibody-drug conjugate gemtuzumab-ozogamicin (GO) [9]. Additional agents that have shown promise include Interferon alfa (IFN $\alpha$ ), unconjugated antibodies, multivalent antibodies, and antibody-drug conjugates [10]. Checkpoint inhibitors, which have been successful in some solid tumors, and CAR-T cells, which have 
activity in lymphoid malignancies, are currently under investigation for use in myeloid malignancies. There are several useful previous reviews describing immunologic agents under investigation for treatment of AML [11-17]; in this review, we update relevant information in the field and also delve into the innate mechanisms of defense against myeloid malignancies, as well as interferon's potential role in treating some of these malignancies.

\section{Innate Immune Cells in the Defense against Myeloid Malignancies}

The cells of the innate immune system are poised to detect various cellular alterations and affect responses directly, as well as indirectly, by activating the adaptive immune system. These alterations include those related to microbial infections as well as markers of stressed cells, such as DNA damage, which can direct innate cells to tumor cells [1]. Three essential components of the innate immune system involved in preventing neoplastic growth are natural killer (NK) cells, dendritic cells, and macrophages.

\subsection{NK Cells}

NK cells are able to recognize foreign elements or altered self and respond directly through various mechanisms. One mechanism, called antibody-dependent cellular cytotoxicity (ADCC), requires the binding of an antibody to the target cell. The CD16a receptor on the NK cell then binds to the fraction crystallizable $(\mathrm{Fc})$ portion of the antibody and triggers degranulation of granzymes and perforin, causing lysis of the target cell [18]. NK cells also trigger caspase-dependent apoptosis of target cells by stimulating death receptors on the target cell's surface [19]. Importantly, DNA damage, a hallmark of tumorigenesis, can upregulate NK ligands on tumor cells [20]. There are multiple preclinical studies showing the ability of NK cells to kill acute and chronic myeloid leukemia cells [21-23]. The expression of NK-activating ligands on AML blasts is linked to positive outcomes in AML patients undergoing chemotherapy [24], and genetic knockout of key NK cell receptors increases tumor formation in mice [25]. There is also evidence that progression of AML, MDS, and CML is inversely correlated with the number and function of NK cells [26]. CAR-NK cells are a novel avenue of treatment and are discussed below.

\subsection{Dendritic Cells}

Dendritic cells are another essential cell type in the innate immune system's defense against malignancies. They are antigen-presenting cells that connect the innate and adaptive immune systems, e.g., by activating anti-tumor T cells. In the context of malignancy, dendritic cells are activated by tumor-derived DNA and other damage-associated molecular patterns (DAMPs) and pathogen-associated molecular patterns (PAMPs) via their expression of pattern recognition receptors $[27,28]$. Once activated, dendritic cells upregulate expression of cytokines, MHC receptors, and co-stimulatory molecules, and they migrate into lymph nodes where they are thought to display their antigen and prime $\mathrm{T}$ cells [29]. Since dendritic cells are able to stimulate cytotoxic T cells, there are multiple dendritic cell-based vaccines in development, utilizing leukemia-associated antigens, though these vaccines are not yet being used in clinical practice [30-32].

\subsection{Macrophages}

Macrophages play a key role in normal tissue homeostasis and inflammatory responses to infections [33]. There are two main subtypes of macrophages, termed M1-like and M2like. M1-like macrophages are "classically activated" (via LPS, IFN $\gamma$, or GM-CSF) and have a pro-inflammatory and anti-tumor phenotype [33]. In contrast, M2-like macrophages are "alternatively-activated" (via IL-4), and they have an immunosuppressive and pro-tumor phenotype [33]. Both types of macrophages can infiltrate tumors, where they become tumor associated macrophages (TAMs). Interestingly, in some studies, tumor infiltration with M1like macrophages corresponds to a favorable prognosis, whereas infiltration with M2-like macrophages correlates with a poor prognosis; in general, the number of M1-like cells tends to decrease during tumor progression [34,35]. M1-like TAMs can eliminate cancer cells by 
driving $\mathrm{T}$ cell proliferation (both cytotoxic $\mathrm{T}$ lymphocytes and $\mathrm{T}$ helper 1 cells), secreting the toxic molecule nitric oxide (NO) and pro-inflammatory cytokines (e.g., IFN $\gamma$, IL-1 $\beta$, IL-12, and TNF $\alpha$ ) [36]. IFN $\gamma$ signaling inhibits angiogenesis and causes cancer cells to upregulate MHC class I receptors, making them more vulnerable to MHC-restricted killing. Unfortunately, cancer cells that have been exposed to IFN $\gamma$ also upregulate molecules such as PD-L1 and indoleamine 2,3 dioxygenase 1 (IDO1) that cause T cell exhaustion and allow tumor progression [36].

Multiple therapies, utilizing the innate ability of macrophages to suppress cancer growth, are under investigation. For example, inhibition of the macrophage checkpoint $\mathrm{CD} 47 / \mathrm{SIRP} \alpha$ is a novel and promising strategy for treatment of AML and MDS, and it is discussed in detail below [37]. Orchestrating a switch from M2-like to M1-like phenotype in TAMs is also a possible therapeutic strategy [36]. For example, one preclinical study found that paclitaxel causes tumor regression by shifting the balance of macrophages from the M2-like phenotype to the M1-like phenotype [38]. Additionally, in another preclinical study, an HDAC inhibitor that induces macrophages, to assume an M1-like phenotype, causes tumor regression in a macrophage-dependent manner [39].

Despite the cancer-preventing abilities of NK cells, dendritic cells, and macrophages, along with other innate immune cells and the adaptive immune system, not all tumor cells are cleared by the immune system, resulting in "immune-edited" tumor cells that are able to proliferate freely. Nevertheless, many successful therapies against myeloid malignancies utilize the immune system in some manner.

\section{Interferon in Myeloid Malignancies}

One of the most important families of genes regulated by the innate immune system is the interferon family. Interferons are cytokines that have multiple functions in infection and cancer [27,40-42]. There are two classes and multiple subtypes of interferons, but for the purposes of this review, we will focus on the type I interferon interferon-alpha (IFN- $\alpha$ ), which is the most clinically-relevant interferon. IFN- $\alpha$ binds to the IFN- $\alpha$ receptor (IFNAR) complex and signals via activation of the JAK-STAT pathway, ultimately causing transcription of interferon-stimulated genes (ISGs) [41,42]. ISGs include pro-apoptotic genes, such as TRAIL and Fas/CD95. IFN $\alpha$ also causes downregulation of cyclins and other cell cycle genes, resulting in G1 arrest. IFN- $\alpha$ is produced endogenously in response to TLR3 activation [41,42]. In addition to exerting effects directly on tumor cells, IFN- $\alpha$ links the innate and adaptive immune systems by enhancing T cell proliferation and survival, and NK cell cytotoxicity [27].

Below, we discuss IFN- $\alpha$ 's role in treatment of the main myeloid malignancies: the myeloproliferative neoplasms (chronic myeloid leukemia (CML), polycythemia vera (PV), essential thrombocythemia (ET), and primary myelofibrosis (PMF), as well as in acute myeloid leukemia (AML) and myelodysplastic syndromes (MDS). A list of recent clinical trials utilizing various formulations of IFN- $\alpha$ for MPNs, MDS, and AML can be found in Hemmati et al. [43].

\section{1. $M P N S$}

CML is a myeloproliferative neoplasm, characterized by a translocation event, resulting in the formation of the Philadelphia chromosome and expression of the BCR-ABL transgene. In the early 1980 's, IFN- $\alpha$ was found to exert anti-proliferative effects on myeloid progenitor cells [44], leading to the hypothesis that it could be used clinically for treatment of MPNs. IFN- $\alpha$ was one of the earliest treatments for chronic myeloid leukemia that was shown to prolong 5-year overall survival (OS) compared to conventional chemotherapy (50-59\% with IFN- $\alpha$ compared to $29-44 \%$ with busulfan or hydroxyurea) [45-47]. One mechanism of interferon-induced CML cell death is thought to involve an increase in Fas receptor on CML progenitor cells [48]. Other proposed mechanisms include interferoninduced expansion of NK cells and $\gamma \delta$-T cells, as well as induction of cytotoxic T cell 
responses $[49,50]$. Thus, IFN- $\alpha$ was the standard frontline treatment for CML until the emergence of molecular targeting in the form of tyrosine kinase inhibitors (TKIs).

Despite the efficacy of TKIs in CML disease control, they are not curative in most cases, and therefore most patients require TKIs indefinitely to keep their disease in check. Additionally, some patients develop resistance to TKI therapy. In order to increase efficacy and sustainability of TKI treatment, IFN- $\alpha$ has been combined with imatinib in multiple clinical trials, such as the German CML-Study IV [51] and French ST157I Prospective Randomized Trial (SPIRIT) [52], reviewed by Talpaz et al. [53]. The SPIRIT trial was a prospective randomized trial for frontline treatment of chronic-phase CML that included over 600 patients in four arms: imatinib $400 \mathrm{mg}$, imatinib $600 \mathrm{mg}$, imatinib $400 \mathrm{mg}+$ cytarabine, and imatinib $400 \mathrm{mg}+$ pegylated interferon alpha2a (PegIFN- $\alpha 2 a)(90 \alpha \mathrm{IIg}$ weekly). Endpoints included molecular and cytogenetic responses, time to treatment failure, OS, event-free survival, and adverse events. Analysis at 12 months revealed a superior rate of molecular response in patients receiving imatinib plus PegIFN- $\alpha 2$ a (30\%) versus $400 \mathrm{mg}$ imatinib alone (14\%) [52]. Patients receiving PegIFN- $\alpha 2 a$, however, had a high rate of discontinuation due to toxicity ( $45 \%$ within the first year), so the dose was reduced. The long-term results of the SPIRIT trial, which was started in 2003, were published in early 2021 [54]. The rate of major molecular response (BCR-ABL transcript level $\leq 0.1 \%$ ) was higher in the imatinib + PegIFN- $\alpha 2 a$ group than imatinib $400 \mathrm{mg}$ alone group ( $59 \%$ vs. $41 \%$, respectively), but this difference did not translate into a difference in progression free survival (PFS) or OS. While the addition of IFN- $\alpha$ to a TKI in this study did not prolong PFS or OS, IFN- $\alpha$ may still have a role in CML treatment, e.g., in the maintenance of remission after TKI discontinuation [55]. There is a phase III trial in progress, comparing PegIFN- $\alpha 2$ a to observation after stopping TKI, in CML patients who have had a deep molecular response for at least 2 years (NCT02381379). In fact, there are over 50 studies either active or completed that are studying various formulations of IFN- $\alpha$ treatment in CML [56].

$\mathrm{PV}$ and ET are myeloproliferative neoplasms that can cause symptoms and pose a risk of progression to acute myeloid leukemia. ET and PV patients are at risk for major bleeding, as well as thrombosis. Low-risk patients are managed with low-dose aspirin, with the addition of phlebotomy in the case of PV. Hydroxyurea is typically the agent of choice for cytoreduction in PV and ET patients, but it does not cause a cytogenetic remission. In ET and PV patients younger than age 65 with disease that is refractory to hydroxyurea, or in cases of intolerance or pregnancy, interferon can be used [57]. For example, one study of weekly IFN- $\alpha$ in PV patients reported a hematologic remission rate of over $80 \%$ [58]. A phase II study, that included both PV and ET patients, reported that $69 \%$ of ET patients and $100 \%$ of PV patients had a response (either PR or CR) to PEG-IFN- $\alpha-2 b$, though this was a small study that included 13 ET patients and only 4 PV patients [59]. A larger trial that included 39 ET patients and $40 \mathrm{PV}$ patients, $81 \%$ of whom had received prior therapy, reported high overall hematologic responses ( $81 \%$ in ET and $80 \%$ in PV) to pegylated IFN- $\alpha$ [60]. Hematologic response was defined as normalization of platelet counts and absence of thromboembolic events in ET, as well as normalization in hematocrit in PV patients (50).

PMF is a myeloproliferative neoplasm associated with recurrent mutations in JAK2 (most frequent), CALR, or MPL, which cause abnormal proliferation of myeloid cells and bone marrow fibrosis. This abnormal myeloid growth results in splenomegaly, constitutional symptoms, and abnormal cell counts. In some cases, PMF can progress to AML. A similar entity, secondary myelofibrosis, occurs in patients initially diagnosed with ET or PV. In some smaller studies, IFN- $\alpha$ has shown some promise for both PMF and secondary myelofibrosis treatment. The first study, suggesting benefits of IFN- $\alpha$ in the treatment of myelofibrosis, was published in 1987 [61]. This study included two symptomatic patients, one with post-PV myelofibrosis and one with PMF, who were treated with daily subcutaneous injections of recombinant IFN- $\alpha-2 c$. Both patients had a reduction in bone pain and improvement in splenomegaly, but they experienced severe cytopenias, requiring multiple dose reductions in IFN- $\alpha$-2c. Ultimately, one of the patients had recurrence of splenomegaly 
at which point treatment was stopped. There have since been more promising reports of IFN- $\alpha$ treatment for primary and secondary myelofibrosis. For example, in one study, treatment with recombinant IFN- $\alpha$, in "early" PMF patients, resulted in stable or improved disease in 14 out of 17 patients [62]. Another study looked retrospectively at patients with primary or secondary myelofibrosis who received at least 6 months of Peg-IFN- $\alpha-2 a$ treatment, and found that $82 \%$ of patients had resolution of their constitutional symptoms, $38.5 \%$ achieved transfusion independence, and $82.8 \%$ achieved complete resolution of their thrombocytosis [63]. Despite some promising results with IFN- $\alpha$ treatment and the development of targeted agents (e.g., the JAK inhibitor ruxolitinib), allogeneic stem cell transplant remains the only curative treatment for PMF.

\section{2. $M D S$ and $A M L$}

MDS is a bone marrow disorder that is characterized by dysfunctional hematopoiesis, leading to cytopenias and variably increased blasts. While MDS cells have multiple genetic mutations and cytogenetic abnormalities, it is likely that immune dysfunction plays a role in the development of the disease as well. Evidence of this dysfunction includes a study looking at bone marrow-derived mesenchymal stem cells from 7 MDS patients (compared with healthy controls) that revealed an upregulation of IFN $\alpha / \beta$ signaling and ISG15 in the MDS-derived samples [64]. Another study found that several of the genes, upregulated in MDS patients' CD34+ cells, were interferon-stimulated genes, such as STAT1, IRF9, interferon-induced protein with tetratricopeptide repeats 1 and 3 (IFIT1 and IFIT3), interferon-induced transmembrane protein 1 (IFITM1), and interferon-induced protein 44-like (IFI44L) [65]. Additionally, IFN- $\gamma$ is overexpressed in the bone marrow of MDS patients [66].

In AML, there are many mechanisms of immune evasion and suppression by the leukemia cells. These may include secretion of cytokines and other factors that alter the bone marrow niche, upregulation of inhibitory T-cell ligands, and expansion of regulatory $\mathrm{T}$ cells and myeloid-derived suppressor cells [67]. A recent study on IFN- $\alpha$ treatment for minimal residual disease (MRD) positive $\mathrm{t}(8 ; 21)$ AML patients after allo-HSCT reported a 2-year OS of $92.3 \%$, compared to $51.4 \%$ in historical cohorts [68]. Another recent study showed a benefit of IFN- $\alpha$ maintenance treatment in favorable-risk AML in reducing risk of relapse [69]. A pilot phase II study of GM-CSF and IFN- $\alpha-2 b$, in patients with relapsed disease (including AML, blast phase CML, and MDS) after allo-HSCT, was conducted (NCT00548847), and results are pending.

\subsection{STING Agonists}

Another strategy utilizing interferon's anti-cancer properties is to stimulate endogenous IFN production, e.g., by activating the stimulator of interferon genes (STING) pathway. Activated STING causes interferon regulatory factor 3 (IRF3) to initiate transcription of type I IFNs as well as other cytokines [70]. In one preclinical model, the STING activator DMXAA showed STING-dependent anti-leukemic activity in a mouse model of AML [71]. There are ongoing preclinical studies of these agents in multiple tumor types (reviewed in $[72,73])$. There is currently a phase I/Ib clinical trial (NCT04144140) using the STING agonist E7766 in patients with advanced tumors or lymphomas. STING agonists are also being studied for use in conjunction with checkpoint inhibitors such as TAK-500 or TAK-676 with pembrolizumab (NCT05070247 and NCT04420884).

\section{Antibody Therapy in AML}

\subsection{Unconjugated Antibodies}

Unconjugated antibodies work by facilitating NK cell function via antibody-dependent cell-mediated cytotoxicity (ADCC). Currently, there are no unconjugated antibodies recommended in the NCCN guidelines for treatment of AML. There are, however, multiple such agents showing promising preclinical data, and some are currently in clinical trials. 
Some of these antibodies target the leukemia cells themselves, while others aim to block the leukemia cells from interacting with their microenvironment.

CD47 is a transmembrane protein that is overexpressed in multiple solid and hematologic malignancies, including AML. CD47 functions by binding to its cognate receptor called Signal Regulatory Protein Alpha (SIRP $\alpha$ ) on macrophages and dendritic cells, leading to disruption of the phagocytic synapse site, and ultimately preventing phagocytosis of the cancer cell. Magrolimab (Hu5F9-G4) is an anti-CD47 monoclonal antibody that targets CD47 on AML blasts, restoring a functional macrophage immune checkpoint. This antibody has shown some efficacy in AML and MDS patients in early phase clinical trials. For example, a phase $\mathrm{Ib}$ trial of the hypomethylating agent azacitidine, in combination with magrolimab, in previously-untreated AML patients unfit for intensive chemotherapy reported an objective response rate (ORR) of $65 \%$. Importantly, there was a 71\% ORR in TP53-mutant AML patients, a traditionally difficult-to-treat population [74]. The ENHANCE clinical trial (NCT04313881) is an ongoing phase III trial comparing safety and efficacy of azacitidine plus magrolimab versus azacitidine plus placebo in previously-untreated patients with high-risk MDS. As of the writing of this review, there are at least five clinical trials involving magrolimab treatment in myeloid malignancies (clinicaltrials.gov), all in combination with azacitidine and / or the BCL-2 inhibitor venetoclax.

CD99 is a transmembrane protein that is frequently overexpressed on AML and MDS cells. Targeted monoclonal antibodies, against CD99, appear active against AML cells and xenografts in preclinical models [75,76]. Evidence suggests that the mechanism of action of anti-CD99 antibodies is via activation of SRC-family kinase (SFK), resulting in oncogenic stress, cell cycle arrest, and apoptosis of leukemia cells [75]. At the writing of this review, there are no clinical trials utilizing anti-CD99 antibodies in treatment of AML or MDS listed on public databases.

CD38 is a glycoprotein that is expressed on AML cells as well as plasma cells; anti-CD38 antibodies such as daratumumab and isatuximab are already approved in the treatment of multiple myeloma. These antibodies bind to CD38 and induce complement-mediated cytotoxicity, ADCC, antibody-dependent cell phagocytosis, and apoptosis. There are preclinical data using AML cell lines or patient-derived AML xenograft mouse models suggesting efficacy of anti-CD38 antibodies [77-79]. Clinical trials using daratumumab (NCT03067571, NCT03537599) and isatuximab (NCT03860844) in AML treatment are ongoing.

FLT3 is a gene that encodes a receptor tyrosine kinase, and is the most frequently mutated gene in AML [80]. FLYSYN is a chimeric Fc-optimized IgG antibody targeted to FLT3 (CD135). A phase I trial (NCT02789254) using FLYSYN in AML patients with minimal residual disease reported good safety and tolerability, as well as a molecular response in $11 / 31$ (35\%) of patients, with an ORR of $46 \%$ in the highest dose arm [81]. An earlier phase I trial with a different FLT3 antibody, LY3012218 (IMC-EB10), showed no clinical activity in relapsed AML [82].

All of the antibodies discussed above target the AML cells directly. Another strategy for AML treatment involves using monoclonal antibodies to disrupt the interaction between leukemia cells and their microenvironment. Ulocuplumab (BMS-936564) is a human IgG4 monoclonal antibody against the G-protein coupled chemokine receptor CXCR4 that prevents it from binding to its ligand, the chemokine CXCL12 (also known as stromal cell-derived factor 1) [83]. When CXCR4 is blocked from binding to CXCL12, leukocytes mobilize from the bone marrow niche into the peripheral blood where they can be exposed to higher levels of chemotherapeutics [84]. Ulocuplumab also causes apoptosis of leukemia blasts ex vivo [84]. A phase I clinical trial, studying the safety and efficacy of ulocuplumab in 73 patients with relapsed/refractory AML in combination with mitoxantrone, etoposide, and cytarabine (MEC) reported an improvement in response rate with this novel combination (CR + CRi of 51\% compared with the historical response rate of $24-28 \%$ with MEC alone [84].

The integrin-binding glycoprotein CD98 also plays an essential role in the proliferation of leukemia cells by engaging them with their microenvironment [85]. This knowledge led 
to the development of the anti-CD98 monoclonal antibody IGN523 and the phase I study of single-agent IGN523 in 19 adult patients with relapsed/refractory AML [86]. Transient anti-leukemic activity was seen in three patients, but no partial or complete responses were observed. Despite this lack of efficacy as a single agent, IMG523 may prove useful in combination with other leukemia-directed therapies. A summary of recent clinical trials, using unconjugated antibodies in AML treatment, can be found in Table 1.

Table 1. Ongoing and recently completed clinical trials of unconjugated antibodies in AML or high-risk MDS. MEC, mitoxantrone, etoposide, and cytarabine. DLI, donor lymphocyte infusion. AZA, azacitidine. Ven, venetoclax. MRD, minimal residual disease.

\begin{tabular}{|c|c|c|c|c|c|}
\hline Drug & Target & $\begin{array}{c}\text { Drug } \\
\text { Combination }\end{array}$ & Phase & NCT Number & Patient Population \\
\hline \multirow{3}{*}{ Magrolimab } & \multirow{4}{*}{ CD47 } & AZA & III & NCT04313881 & $\begin{array}{l}\text { Previously untreated } \\
\text { high-risk MDS }\end{array}$ \\
\hline & & $\mathrm{AZA}+\mathrm{Ven}$ & III & NCT05079230 & $\begin{array}{l}\text { Newly diagnosed AML } \\
\text { ineligible for intensive } \\
\text { chemotherapy }\end{array}$ \\
\hline & & AZA & III & NCT04778397 & $\begin{array}{c}\text { Newly diagnosed TP53 } \\
\text { mutant AML }\end{array}$ \\
\hline AK117 & & AZA & I/II & NCT04980885 & $\begin{array}{l}\text { AML without favorable } \\
\text { risk cytogenetics }\end{array}$ \\
\hline \multirow{2}{*}{ Daratumumab } & \multirow{3}{*}{ CD38 } & $\mathrm{N} / \mathrm{A}$ & II & NCT03067571 & $\begin{array}{c}\mathrm{R} / \mathrm{R} \text { AML or high-risk } \\
\text { MDS }\end{array}$ \\
\hline & & DLI & I/II & NCT03537599 & $\begin{array}{l}\text { Relapsed AML after } \\
\text { stem cell transplant }\end{array}$ \\
\hline Isatuximab & & Chemotherapy & II & NCT03860844 & $\begin{array}{l}\text { Pediatric patients with } \\
\mathrm{R} / \mathrm{R} \text { ALL or AML in } \\
\text { first or second relapse }\end{array}$ \\
\hline FLYSYN & FLT3 (CD135) & $\mathrm{N} / \mathrm{A}$ & I & NCT02789254 & AML patients with MRD \\
\hline $\begin{array}{l}\text { PF-04518600 } \\
\quad(O X 40)\end{array}$ & CD134 & $\begin{array}{c}\text { AZA, ven, } \\
\text { glasdegib, } \\
\text { avelumab, GO }\end{array}$ & $\mathrm{I} / \mathrm{II}$ & NCT03390296 & $\mathrm{R} / \mathrm{R} \mathrm{AML}$ \\
\hline Hu5F9-G4 & CD47 & Atezolizumab & $\mathrm{Ib}$ & NCT03922477 & R/R AML \\
\hline Talacotuzumab & CD123 & Decitabine & II/III & NCT02472145 & $\begin{array}{c}\text { AML ineligible for } \\
\text { intensive chemotherapy }\end{array}$ \\
\hline Cusatuzumab & CD70 & Ven & $\mathrm{Ib}$ & NCT04150887 & $\begin{array}{l}\text { Previously-untreated } \\
\text { AML ineligible for } \\
\text { intensive chemotherapy }\end{array}$ \\
\hline IO-202 & LILRB4 & $\mathrm{N} / \mathrm{A}$ & I & NCT04372433 & R/R AMML and CMML \\
\hline
\end{tabular}

\subsection{Multivalent Antibodies}

The purpose of using multivalent antibodies is to increase the immune response to tumor cells by physically approximating the two cell types. Bispecific T-cell engagers (BiTEs) are one type of multivalent antibody [87]. They are engineered to link two antibodies: one that targets the antigen of interest on the cancer cell, and one that is directed to the CD3 receptor on $\mathrm{T}$ cells. Once the BiTE is bound to $\mathrm{CD} 3$, the $\mathrm{T}$ cell receptor is stimulated and activates a cytotoxic response against the blast cell [88]. This specific interaction decreases the risk of off-target toxicity, as these $\mathrm{T}$ cells are only activated near blast cells. BiTE molecules are very small and can be rapidly excreted by the kidney; thus, the new generation of BiTEs are being designed to have a longer half-life [89]. There are various antigens of interest on blast cells that could theoretically serve as targets for BiTEs, however, it is important that the antigens meet certain criteria in order to serve as effective targets. For example, 
the antigens should have high expression on blast cells and low, or absent, expression on normal hematopoietic cells.

There are multiple BiTE therapies that have been developed and studied in AML. The first BiTE therapy developed in myeloid malignancies was against CD33 (AMG 330). The BiTE molecule binds to the IPYYDKN amino acid sequence within the CD33 V type domain on blast cells and engages it with CD3 on T cells, resulting in T cell activation, expansion, and cytotoxic killing. In a study by Ravandi et al., 55 patients with relapsed/refractory AML received AMG 330; the ORR was $19 \%$, and CR was $7 \%$. The main adverse event, experienced in $60 \%$ of patients, was cytokine release syndrome (CRS) [90]. Subklewe et al. used a newer generation CD33 BiTE (AMG 673) which has an extended half-life. In that study, 30 patients were enrolled, $44 \%$ of patients had a reduction in blast count in the bone marrow, and $50 \%$ of patients developed CRS [91].

Due to the increased expression of CD123 on AML cells, multiple BiTE therapies have been developed using that target. Ravandi et al. reported a study that evaluated the CD123-targeted BiTE ibecotamab in 103 relapsed/refractory AML patients [92]. The ORR in that study was $14 \%$, and four patients had a CR. Interestingly, $71 \%$ of patients had stable disease. Of note, CRS was observed in 59\% of the patients. Talacotuzumab (another CD123 BiTE) has been evaluated in a phase II/III study in combination with decitabine (compared to decitabine alone) [93]. This study enrolled 316 older AML patients that are ineligible for intensive chemotherapy. The combination therapy yielded OS and CR rates that are similar to single agent decitabine (median OS: 5.36 months with combination vs. 7.26 months for decitabine alone with HR: 1.04; 95\% CI: 0.79-1.37; $p=0.78$ ) (CR: 15\% vs. $11 \%$; odds ratio: $1.4 ; 95 \% \mathrm{CI}: 0.6-3.6 ; p=0.44)$. Flotetuzumab is a newer generation CD123 BiTE called a dual affinity retargeting antibody (DART) that consists of a diabody backbone with the addition of a c-terminal disulfide bridge that is aimed to increase stabilization of the molecule. In a study by Uy et al., flotetuzumab was evaluated in 30 patients with relapsed/refractory AML [94]. The ORR in that study was $27 \%$, with a median OS of 10.2 months in the responders. This study, however, reported a $100 \%$ rate of CRS.

Given limited responses observed in targeting CD33 and CD123, other specific targets on AML blasts are being evaluated. For example, AMG 427 and BiTE 7370, which are novel anti-FLT3 x CD3 BiTEs, are being evaluated in relapsed/refractory AML [95,96]. In preclinical studies, treatment with AMG 427 causes an upregulation of PD-1 expression on T cells, decreasing the potency of AMG 427 against AML cells that express PD-L1; the addition of PD-1 blockade, however, restored AMG 427 potency in clearing blast cells [96]. In order to improve the limited response seen with BiTEs, multiple preclinical studies are evaluating the combination of FDA-approved therapies with BiTEs. One study evaluated the effect of adding venetoclax to CD123 BiTE therapy and showed that there was a dosedependent blast reduction in mouse models in the combination arm compared to BiTE therapy alone [97].

Table 2 summarizes recent and ongoing clinical trials utilizing multivalent antibodies in the treatment of myeloid malignancies. Although a promising technology, so far, studies with multivalent antibodies have not shown major efficacy. Thus, the future utility of these agents may be dependent on combinations with other antileukemic agents. 
Table 2. Recent clinical trials of multivalent antibodies for AML. All trials are for adults only. TriKE, tri-specific killer cell engager. R/R, relapsed/refractory. MRD, minimal residual disease. DART, dual-affinity retargeting antibody.

\begin{tabular}{|c|c|c|c|c|c|}
\hline Drug & Targets & Phase & NCT Number & Patient Population & Drug Type \\
\hline MCLA-117 & CLEC12A $\times$ CD3 & I & NCT03038230 & $\begin{array}{c}\text {-R/R AML } \\
\text {-newly diagnosed AML in elderly } \\
\text { patients with high-risk cytogenetics } \\
\text {-very high risk MDS with R/R disease }\end{array}$ & $\begin{array}{l}\text { Bispecific } \\
\text { antibody }\end{array}$ \\
\hline AMG 330 & \multirow{4}{*}{$\mathrm{CD} 33 \times \mathrm{CD} 3$} & I & NCT02520427 & $\begin{array}{l}-\mathrm{R} / \mathrm{R} \text { AML } \\
-\mathrm{MRD}+\mathrm{AML} \\
-\mathrm{MDS}\end{array}$ & BiTE \\
\hline AMG 673 & & I & NCT03224819 & R/R AML & BiTE \\
\hline GEM333 & & $\mathrm{I}$ & NCT03516760 & $\begin{array}{l}\text { CD33+ AML: R/R, or not eligible for } \\
\text { standard induction therapy and } \\
\text { refractory to or progressive after HMAs }\end{array}$ & BiTE \\
\hline JNJ-67371244 & & I & NCT03915379 & $\begin{array}{c}-\mathrm{R} / \mathrm{R} \text { AML } \\
\text {-high or very high risk MDS }\end{array}$ & BiTE \\
\hline $\begin{array}{l}\text { Vibecotamab } \\
\text { (XmAb14045) }\end{array}$ & \multirow{4}{*}{$\mathrm{CD} 123 \times \mathrm{CD} 3$} & I & NCT02730312 & $\begin{array}{c}\text {-Primary or secondary AML } \\
\text {-B-ALL } \\
\text {-BPDCN } \\
\text {-Blast phase CML resistant or intolerant } \\
\text { to TKIs }\end{array}$ & BiTE \\
\hline JNJ-63709178 & & I & NCT02715011 & R/R AML & DuoBody \\
\hline Flotetuzumab & & $\mathrm{I} / \mathrm{II}$ & NCT02152956 & $\begin{array}{l}\text { Primary induction failure/early relapsed } \\
\text { AML }\end{array}$ & DART \\
\hline $\begin{array}{l}\text { Talacotuzumab } \\
\text { (+ decitabine vs. } \\
\text { decitabine alone) }\end{array}$ & & II/III & NCT02462145 & $\begin{array}{l}\text { AML not eligible for standard induction } \\
\text { therapy }\end{array}$ & BiTE \\
\hline GTB-3550 & $\begin{array}{l}\mathrm{CD} 16 \times \mathrm{IL}-15 \times \\
\mathrm{CD} 33\end{array}$ & $\mathrm{I} / \mathrm{II}$ & NCT03214666 & $\begin{array}{c}\text { CD33+: } \\
\text {-R/R AML } \\
\text {-High-risk MDS } \\
\text {-advanced systemic mastocytosis }\end{array}$ & TriKE \\
\hline LAVA-051 & $\mathrm{CD} 1 \mathrm{~d} \times \mathrm{TCR}$ & $\mathrm{I} / \mathrm{II}$ & NCT04887259 & R/R CD1d+ CLL, MM, and AML & BiTE \\
\hline AMG 427 & FLT3 $\times$ CD3 & I & NCT03541369 & R/R AML & BiTE \\
\hline
\end{tabular}

\subsection{Antibody-Drug Conjugates (ADCs)}

ADCs are monoclonal antibodies that are conjugated to various cytotoxic agents via a linker molecule [98]. The target antigen for the ADCs is usually a relatively specific blast cell surface antigen with limited expression on healthy tissues [99]. The linker molecule is designed to stabilize the ADC in circulation and prevent the premature release of the attached cytotoxic agents, thereby maximizing the drug exposure of the target cells. Once the antibody is bound to the target receptor, the receptor-antibody complex is endocytosed, and ultimately, the cytotoxic agent is released inside the target cell. The cytotoxic agents, either chemotherapy or bacteria-derived toxins, usually target the DNA or microtubules, resulting in blast cell death [87].

Currently, the only FDA-approved ADC in AML is gemtuzumab ozogamicin (GO). This ADC is a humanized anti-CD33 monoclonal antibody that is conjugated to calicheamicin, which is a bacterial toxin that binds the DNA and causes strand scission [100]. GO was initially approved in 2000, based on its clinical efficacy in AML in a phase II study [101]. However, it was subsequently pulled from the market due to an increasing incidence of sinusoidal obstructive syndrome (SOS) and mortality [101,102]. Notably, GO was given without dose capping, and some patients who received GO subsequently underwent a stem cell transplant, which also increases the risk of SOS. After multiple studies, that 
evaluated lower doses of GO in combination therapy, showed efficacy with a much lower risk of SOS in patients with favorable cytogenetics, it was re-approved by the FDA [103]. It should be noted, however, that the agent has no significant activity in cases with poor cytogenetics [104].

There are multiple other CD33-directed ADCs. Actinium-225 $\left({ }^{225} \mathrm{Ac}\right)$-lintuzumab is a radioimmunoconjugate composed of ${ }^{225} \mathrm{Ac}$ conjugated to a CD33 antibody. A single arm phase II study of ${ }^{225}$ Ac-lintuzumab in older patients with untreated AML reported preliminary results with a 56\% ORR [105]. Further studies using ${ }^{225} \mathrm{Ac}-$ lintuzumab, in combination with other treatments such as salvage chemotherapy or venetoclax, are planned [105]. Vadastuximab talirine (SGN-CD33A) is an ADC which incorporates a cytotoxic synthetic DNA crosslinking pyrrolobenzodiazepene dimer to CD33 [106]. One study evaluated this ADC in combination with azacitidine in the frontline setting for patients above age 60 and reported an overall response rate (CR/CRi) of $70 \%$ with high MRD negativity [107]. However, a subsequent randomized placebo-controlled study was discontinued due to increased mortality that is likely due to bone marrow suppression, as CD33 is expressed on normal hematopoietic stem cells and increased toxicity from the cytotoxic agent pyrrolobenzodiazepene. This toxicity highlights the critical need to identify other AML-specific targets (NCT02785900).

IMGN632 is an ADC that binds to a different target: CD123. CD123 is an IL-3 receptor alpha chain that is highly expressed on AML blasts, but also expressed on endothelial cells and hematopoietic stem cells [108]. IMGN632 links a CD123 antibody to an indolinobenzodiazepine pseudo-dimer. A phase I/Ib study, evaluating this ADC in 66 patients with AML, showed a response rate of $20 \%(4 \% \mathrm{CR}, 12 \% \mathrm{CRi}, 3 \%$ morphologic leukemia free state), which is the basis of a phase II study with HMA and venetoclax treatment in patients who are not candidates for intensive chemotherapy [109]. AGS 62P1 (ASP 1235) is an ADC that links a FLT3 antibody to AGL-0182-30, a microtubule-disrupting agent [109,110]. Early phase studies are showing potent cytotoxicity towards FLT3-mutated AML cells [111]. Finally, iodine-131 (131 iodine) apamistamab (Iomab-B), an ADC that links a CD45 antibody to radiolabeled ${ }^{131}$ iodine, is being evaluated in patients who are unable to tolerate standard high-dose myeloablative HSCT pre-conditioning, is showing promising results and a decreased risk of mucositis, neutropenic fevers, and sepsis [112].

\section{Checkpoint Inhibitors}

Immune check point inhibitors (ICI), such as PD-1 and CTLA-4 antibodies, have transformed the treatment of many cancers, including some hematological malignancies [113]. However, thus far their efficacy in myeloid malignancies has been limited. Hypomethylating agents (HMAs) have efficacy in AML and MDS and are known to modify immune activation in several ways; however, they also increase immune checkpoints, leading to the idea of combining HMAs with ICIs [114]. One study that evaluated the use of the anti-PD-1 antibody nivolumab in combination with azacitidine in relapsed/refractory AML reported an ORR of $18 \%$ and median OS of 9.3 months; interestingly, the subset of patients who had not been previously exposed to HMAs had an overall response rate of 52\% [115]. Another study evaluated the use of the anti-CTLA- 4 antibody ipilimumab in 28 patients with relapsed hematological malignancies after stem cell transplant, 12 of which had AML. This study showed no response with the lower dose of ipilimumab $(3 \mathrm{mg} / \mathrm{kg})$, but there was an ORR of $55 \%$ in patients receiving the higher dose $(10 \mathrm{mg} / \mathrm{kg})$ [116]. Finally, another study evaluated ipilimumab, in 29 patients with MDS who failed a prior hypomethylating agent, and showed a median OS of 294 days (with censoring of transplanted patients) [117]. As with other cancer types, biomarkers will likely play a role in selecting the subset of patients who will respond to ICI. For example, in the nivolumab plus azacitidine study, those with a pre-existing $\mathrm{T}$ cell infiltration and higher CD3+, CD8+ lymphocyte percentage in the pre-treatment bone marrow had the best chance of response [115]. Clinical studies on checkpoint inhibitors in AML and other myeloid malignancies are summarized in Table 3. 
Table 3. Clinical trials using checkpoint inhibitors for the treatment of myeloid malignancies. T-AML, therapy-related AML. $\mathrm{R} / \mathrm{R}$. relapsed/refractory. DLI, donor lymphocyte infusion. MPAL, mixed phenotype acute leukemia. CMML, chronic myelomonocytic leukemia. AZA, azacitidine.

\begin{tabular}{|c|c|c|c|c|c|}
\hline Drug & Target & Phase & $\begin{array}{l}\text { NCT } \\
\text { Number }\end{array}$ & Patient Population & Intervention \\
\hline \multirow{2}{*}{ Ipilimumab } & CTLA-4 & I & NCT02890329 & R/R MDS/AML & Ipilimumab + decitabine \\
\hline & & I & NCT03912064 & $\begin{array}{c}\text { Relapsed AML, MDS, or MPN } \\
\text { after allo-HSCT }\end{array}$ & $\begin{array}{c}\text { Ipilimumab + } \\
\text { CD25/Treg-depleted DLI }\end{array}$ \\
\hline \multirow[t]{2}{*}{ Durvalumab } & PD-L1 & I & NCT02117219 & MDS & $\begin{array}{c}\text { Durvalumab + AZA, } \\
\text { durvalumab + tremelimumab }\end{array}$ \\
\hline & & II & NCT02775903 & $\begin{array}{l}\text { High risk MDS, elderly AML } \\
\text { patients }\end{array}$ & Durvalumab + AZA \\
\hline \multirow[t]{9}{*}{ Pembrolizumab } & PD-1 & $\mathrm{I}$ & NCT04284787 & AML, t-AML, AML with MRC & $\begin{array}{l}\text { Pembrolizumab + induction } \\
\text { chemo or venetoclax }+ \text { AZA }\end{array}$ \\
\hline & & I & NCT02981914 & $\begin{array}{l}\text { Hematologic malignancy with } \\
\text { relapse after allo-HSCT }\end{array}$ & Pembrolizumab \\
\hline & & I & NCT03286114 & Relapsed MDS/AML & Pembrolizumab \\
\hline & & I & NCT03969446 & Newly diagnosed AML, MDS & Pembrolizumab + Decitabine \\
\hline & & II & NCT02768792 & $\mathrm{R} / \mathrm{R}$ AML & $\begin{array}{l}\text { Pembrolizumab following } \\
\text { HiDAC salvage induction }\end{array}$ \\
\hline & & II & NCT02845297 & $\begin{array}{l}\mathrm{R} / \mathrm{R} \text { MDS / AML and newly } \\
\text { diagnosed AML patients }>65\end{array}$ & $\mathrm{AZA}+$ pembrolizumab \\
\hline & & II & NCT02996474 & $\mathrm{R} / \mathrm{R} \mathrm{AML}$ & Pembrolizumab + decitabine \\
\hline & & II & NCT02708641 & $\begin{array}{l}\text { AML >60 in remission and not } \\
\text { transplant candidates }\end{array}$ & Pembrolizumab \\
\hline & & II & NCT02771197 & $\begin{array}{l}\text { AML patients with high risk of } \\
\text { relapse }\end{array}$ & $\begin{array}{c}\text { Pembrolizumab }+ \\
\text { Fludarabine/melphalan }+ \\
\text { auto-HSCT }\end{array}$ \\
\hline \multirow[t]{9}{*}{ Nivolumab } & PD-1 & II & NCT03600155 & R/R AML after HCT & Ipilimumab, Nivolumab \\
\hline & & II & NCT02275533 & Post remission AML & Nivolumab \\
\hline & & II & NCT02532231 & AML with high risk of relapse & Nivolumab \\
\hline & & $\mathrm{I} / \mathrm{II}$ & NCT02464657 & AML/MDS & Nivolumab \& 7+3 induction \\
\hline & & II & NCT02397720 & MDS/RR-AML, MPAL, CMML & $\begin{array}{l}\text { Nivolumab + AZA +/- } \\
\text { ipilimumab }\end{array}$ \\
\hline & & I & NCT02846376 & AML \& MDS after SCT & Nivolumab + ipilimumab \\
\hline & & $\mathrm{I}$ & NCT01822509 & $\begin{array}{c}\text { Hematologic malignancy with } \\
\text { relapse after allo-HSCT }\end{array}$ & Nivolumab or Ipilimumab \\
\hline & & II & NCT04913922 & $\begin{array}{c}\text { R/R-AML and patients } \geq 65 \text { with } \\
\text { newly diagnosed AML }\end{array}$ & $\begin{array}{c}\text { AZA + nivolumab + relatlimab } \\
\text { [Anti-LAG3] }\end{array}$ \\
\hline & & $\mathrm{II} / \mathrm{III}$ & NCT03092674 & $\begin{array}{l}\text { Elderly patients with MDS or } \\
\text { newly diagnosed AML }\end{array}$ & $\begin{array}{c}\mathrm{AZA}+/- \text { nivolumab or } \\
\text { midostaurin, or decitabine }+ \\
\text { cytarabine }\end{array}$ \\
\hline MBG453 & TIM-3 & I & NCT03066648 & AML/MDS & $\begin{array}{c}\text { MBG453 + decitabine, or + } \\
\text { PDR001 (anti-PD-I antibody) }\end{array}$ \\
\hline
\end{tabular}

\section{CAR-T and CAR-NK Cells in AML}

Chimeric antigen receptor (CAR) T-cell therapy is an exciting novel therapeutic approach that is showing promise in lymphomas and multiple myeloma [118]. Furthermore, CAR-T therapies have received US Food and Drug Administration (FDA) approval in 
relapsed/refractory acute lymphocytic leukemia with CAR-T directed against CD19 [119]. However, CAR-T trials are still in the early stages of development in AML/MDS. The two most studied targets for CAR-T therapies in myeloid malignancies are CD33 and CD123. NCT03795779 is a trial currently recruiting patients with relapsed and refractory myeloid malignancies for treatment with a CD33-CLL1 (C-type lectin molecule-1) compound CAR-T and results are awaited.

As discussed previously, CD123 is highly expressed on AML blasts, but it is also expressed on endothelial cells and hematopoietic stem cells [108]. As a result, trials that evaluated CD123 CARTs have encountered complications of capillary leak syndrome (CLS) in addition to CRS, especially in patients with heavy disease burden [120]. To prevent these life-threatening adverse events, newer trials are using biodegradable CD123 CAR-Ts that are manufactured by electroporation of mRNA encoding the CAR, rather than T cells transduced with lentivirus, resulting in transient (rather than permanent) expression of the chimeric antigen receptor [121]. While this approach should decrease the persistence of CAR-Ts and, therefore, the risk of CLS, it will likely require repeated dosing [122]. Another issue with targeting CD123 is that, because it is present on normal HSCs, healthy HSCs may be destroyed during treatment. Therefore, patients who receive CD123 CAR$\mathrm{T}$ may need a rescue allogenic stem cell transplant to repopulate their hematopoietic stem cell compartment. For example, a second generation CD123 CAR-T (CD123CAR41BB-CD3C) trial (NCT03766126) plans to use allo-HSCT as a rescue strategy if patients experience prolonged marrow aplasia. Given these challenges in CAR-T therapies in myeloid malignancies, there are extensive efforts to find new targets; NKG2D, ADGRE2, CCR1, CD70, and LILRB2 are promising targets [123]. In addition, there is interest in developing dual CAR-CAR-T (CAR-T with 2 CAR antigens) or combination therapies of two different CAR-Ts [124,125].

NK cells, as discussed above, are part of the innate immune system, and they are able to recognize the absence of certain proteins that may be downregulated on malignant cells, such as HLA proteins. They also have the ability to kill tumor cells directly. Thus, NK cells can be engineered to target cancer cells, such as CAR-T cells. In fact, CAR-NK cell therapies are emerging as a promising new treatment [126]. Unlike CAR-T cells, CARNK cells do not carry the risk of graft-versus-host disease (GvHD) and, therefore, could be engineered as an off-the-shelf product that would be readily available for immediate clinical use [127]. Recently, the first in human phase I study with CAR-NK was reported and involved three patients with relapsed/refractory AML treated with anti-CD33 CAR NK-92 [128]. These NK-92 CARs are third-generation CARs that incorporate both CD28 and $4-1 \mathrm{BB}$ co-stimulatory molecules. This study established the safety of escalating doses of CAR-transduced NK-92 cell infusions; however, no durable responses were achieved. NCT02944162 is the phase II study that will evaluate the efficacy of NK-92 CAR with the highest dose. Currently, there is a phase I study evaluating NKX101 CART which are allogeneic CAR-NK cells targeting NKG2D ligands in patients with relapsed/refractory AML and high risk MDS (NCT04623944). The NK cells are derived either from haplomatched related donors or unrelated off-the-shelf donors.

\section{Discussion}

The immune system plays an essential role, in preventing tumor formation, by recognizing and killing cells that have become altered from normal "self." Although the immune system has redundant mechanisms of surveilling for tumors, neoplastic cells are able to suppress or subvert these mechanisms. Manipulation of the immune system, however, is a strategy that is growing increasingly effective against malignancies. From interferon, which has been used to treat myeloid malignancies for decades, to the promise of CAR-T and CAR-NK cells, immuno-oncology appears to be a longstanding fixture in the treatment of myeloid malignancies. Each of these strategies has its own set of limitations and side effects. Most immune-mediated strategies require the targeting of an AML antigen; however, it is difficult to find tumor antigens that are unique to the AML cells, and the downregulation 
of these antigens by the tumor cells is a common mechanism of resistance. Additionally, all immunotherapy-based strategies present a risk of autoimmune or inflammatory complications in patients, as well as a high risk of graft versus host disease in patients that have relapsed post-allo-HSCT. Despite the numerous immunotherapy agents mentioned above, few have been successful in clinical trials, which may be due, in part, to biological mechanisms of resistance that are yet to be delineated. Additionally, it will be important to continue identifying biomarkers for response to immunotherapy.

Author Contributions: Conceptualization, L.C.P. and S.S.; writing, original draft preparation, S.S. and Y.N.; writing-review and editing, L.C.P. and S.S. All authors have read and agreed to the published version of the manuscript.

Funding: The research of L.C.P. is supported by grants R01-CA77816, R01-CA121192 and I01-CX000916.

Institutional Review Board Statement: Not applicable.

Informed Consent Statement: Not applicable.

Data Availability Statement: Not applicable.

Conflicts of Interest: The authors declare no conflict of interest.

\section{References}

1. DeMaria, O.; Cornen, S.; Daëron, M.; Morel, Y.; Medzhitov, R.; Vivier, E. Harnessing innate immunity in cancer therapy. Nature 2019, 574, 45-56. [CrossRef]

2. Esfahani, K.; Roudaia, L.; Buhlaiga, N.; Del Rincon, S.; Papneja, N.; Miller, W. A Review of Cancer Immunotherapy: From the Past, to the Present, to the Future. Curr. Oncol. 2020, 27, 87-97. [CrossRef]

3. Marshall, H.T.; Djamgoz, M.B.A. Immuno-Oncology: Emerging Targets and Combination Therapies. Front. Oncol. 2018, 8, 315. [CrossRef]

4. Zhang, X.; Wang, S.; Zhu, Y.; Zhang, M.; Zhao, Y.; Yan, Z.; Wang, Q.; Li, X. Double-edged effects of interferons on the regulation of cancer-immunity cycle. OncoImmunology 2021, 10, 1929005. [CrossRef]

5. Miliotou, A.; Papadopoulou, L. CAR T-cell Therapy: A New Era in Cancer Immunotherapy. Curr. Pharm. Biotechnol. 2018, 19, 5-18. [CrossRef]

6. Dickinson, A.M.; Norden, J.; Li, S.; Hromadnikova, I.; Schmid, C.; Schmetzer, H.; Jochem-Kolb, H. Graft-versus-Leukemia Effect Following Hematopoietic Stem Cell Transplantation for Leukemia. Front. Immunol. 2017, 8, 496. [CrossRef]

7. Gratwohl, A.; Baldomero, H.; Passweg, J.; Frassoni, F.; Niederwieser, D.; Schmitz, N. Hematopoietic stem cell transplantation for hematological malignancies in Europe. Leukemia 2003, 17, 941-959. [CrossRef]

8. Kuykendall, A.; Duployez, N.; Boissel, N.; Lancet, J.E.; Welch, J.S. Acute Myeloid Leukemia: The Good, the Bad, and the Ugly. Am. Soc. Clin. Oncol. Educ. Book 2018, 38, 555-573. [CrossRef]

9. Tallman, M.S.; Pollyea, D.A. AML (Version 3.2021) National Comprehensive Cancer Network. Available online: https://www. nccn.org/professionals/physician_gls/pdf/aml.pdf (accessed on 8 September 2021).

10. Williams, B.A.; Law, A.; Hunyadkurti, J.; Desilets, S.; Leyton, J.V.; Keating, A. Antibody Therapies for Acute Myeloid Leukemia: Unconjugated, Toxin-Conjugated, Radio-Conjugated and Multivalent Formats. J. Clin. Med. 2019, 8, 1261. [CrossRef]

11. Isidori, A.; Cerchione, C.; Daver, N.; DiNardo, C.; Garcia-Manero, G.; Konopleva, M.; Jabbour, E.; Ravandi, F.; Kadia, T.; Burguera, A.D.L.F.; et al. Immunotherapy in Acute Myeloid Leukemia: Where We Stand. Front. Oncol. 2021, 11, 656218. [CrossRef]

12. Kantarjian, H.; Kadia, T.; DiNardo, C.; Daver, N.; Borthakur, G.; Jabbour, E.; Garcia-Manero, G.; Konopleva, M.; Ravandi, F. Acute myeloid leukemia: Current progress and future directions. Blood Cancer J. 2021, 11, 1-25. [CrossRef]

13. Tabata, R.; Chi, S.; Yuda, J.; Minami, Y. Emerging Immunotherapy for Acute Myeloid Leukemia. Int. J. Mol. Sci. 2021, 22, 1944. [CrossRef]

14. Vago, L.; Gojo, I. Immune escape and immunotherapy of acute myeloid leukemia. J. Clin. Investig. 2020, 130, 1552-1564. [CrossRef]

15. Daver, N.; Alotaibi, A.S.; Bücklein, V.; Subklewe, M. T-cell-based immunotherapy of acute myeloid leukemia: Current concepts and future developments. Leukemia 2021, 35, 1843-1863. [CrossRef]

16. Carnevalli, L.S.; Ghadially, H.; Barry, S.T. Therapeutic Approaches Targeting the Natural Killer-Myeloid Cell Axis in the Tumor Microenvironment. Front. Immunol. 2021, 12, 633685. [CrossRef]

17. Sendker, S.; Reinhardt, D.; Niktoreh, N. Redirecting the Immune Microenvironment in Acute Myeloid Leukemia. Cancers 2021, 13, 1423. [CrossRef]

18. Bryceson, Y.; March, M.; Barber, D.F.; Ljunggren, H.-G.; Long, E.O. Cytolytic granule polarization and degranulation controlled by different receptors in resting NK cells. J. Exp. Med. 2005, 202, 1001-1012. [CrossRef]

19. Screpanti, V.; Wallin, R.P.A.; Ljunggren, H.-G.; Grandien, A. A Central Role for Death Receptor-Mediated Apoptosis in the Rejection of Tumors by NK Cells. J. Immunol. 2001, 167, 2068-2073. [CrossRef] 
20. Raulet, D.H.; Guerra, N. Oncogenic stress sensed by the immune system: Role of natural killer cell receptors. Nat. Rev. Immunol. 2009, 9, 568-580. [CrossRef]

21. Yan, Y.; Steinherz, P.; Klingemann, H.G.; Dennig, D.; Childs, B.H.; McGuirk, J.; O’Reilly, R.J. Antileukemia activity of a natural killer cell line against human leukemias. Clin. Cancer Res. 1998, 4, 2859-2868.

22. Pattengale, P.K.; Sundstrom, C.; Yu, A.; Levine, A. Lysis of fresh leukemic blasts by interferon-activated human natural killer cells. Nat. Immun. Cell Growth Regul. 1983, 3, 165-180.

23. Schlegel, P.; Ditthard, K.; Lang, P.; Mezger, M.; Michaelis, S.; Handgretinger, R.; Pfeiffer, M. NKG2D Signaling Leads to NK Cell Mediated Lysis of Childhood AML. J. Immunol. Res. 2015, 2015, 473175. [CrossRef]

24. Mastaglio, S.; Wong, E.; Perera, T.; Ripley, J.; Blombery, P.; Smyth, M.J.; Koldej, R.; Ritchie, D. Natural killer receptor ligand expression on acute myeloid leukemia impacts survival and relapse after chemotherapy. Blood Adv. 2018, 2, 335-346. [CrossRef]

25. Guerra, N.; Tan, Y.X.; Joncker, N.T.; Choy, A.; Gallardo, F.; Xiong, N.; Susan, K.; Cado, D.; Greenberg, N.R.; Raulet, D.H. NKG2D-deficient mice are defective in tumor surveillance in models of spontaneous malignancy. Immunity 2008, 28, 571-580. [CrossRef]

26. Carlsten, M.; Järås, M. Natural Killer Cells in Myeloid Malignancies: Immune Surveillance, NK Cell Dysfunction, and Pharmacological Opportunities to Bolster the Endogenous NK Cells. Front. Immunol. 2019, 10, 2357. [CrossRef]

27. Fenton, S.; Saleiro, D.; Platanias, L. Type I and II Interferons in the Anti-Tumor Immune Response. Cancers 2021, $13,1037$. [CrossRef]

28. Wculek, S.; Cueto, F.J.; Mujal, A.M.; Melero, I.; Krummel, M.F.; Sancho, D. Dendritic cells in cancer immunology and immunotherapy. Nat. Rev. Immunol. 2019, 20, 7-24. [CrossRef]

29. Gardner, A.; Pulido, D.M.; Ruffell, B. Dendritic Cells and Their Role in Immunotherapy. Front. Immunol. 2020, 11, 924. [CrossRef]

30. Schürch, C. Therapeutic Antibodies for Myeloid Neoplasms-Current Developments and Future Directions. Front. Oncol. 2018, 8, 152. [CrossRef]

31. Anguille, S.; Willemen, Y.; Lion, E.; Smits, E.; Berneman, Z. Dendritic cell vaccination in acute myeloid leukemia. Cytotherapy 2012, 14, 647-656. [CrossRef]

32. Van de Loosdrecht, A.A.; van Wetering, S.; Santegoets, S.; Singh, S.K.; Eeltink, C.M.; den Hartog, Y.; Koppes, M.; Kaspers, J.; Ossenkoppele, G.J.; Kruisbeek, A.M.; et al. A novel allogeneic off-the-shelf dendritic cell vaccine for post-remission treatment of elderly patients with acute myeloid leukemia. Cancer Immunol. Immunother. 2018, 67, 1505-1518. [CrossRef]

33. Cendrowicz, E.; Sas, Z.; Bremer, E.; Rygiel, T. The Role of Macrophages in Cancer Development and Therapy. Cancers 2021, 13, 1946. [CrossRef]

34. Bruni, D.; Angell, H.K.; Galon, J. The immune contexture and Immunoscore in cancer prognosis and therapeutic efficacy. Nat. Rev. Cancer 2020, 20, 662-680. [CrossRef] [PubMed]

35. Garrido-Martin, E.M.; Mellows, T.W.P.; Clarke, J.; Ganesan, A.-P.; Wood, O.; Cazaly, A.; Seumois, G.; Chee, S.J.; Alzetani, A.; King, E.V.; et al. M1hot tumor-associated macrophages boost tissue-resident memory T cells infiltration and survival in human lung cancer. J. Immunother. Cancer 2020, 8, e000778. [CrossRef]

36. Najafi, M.; Goradel, N.H.; Farhood, B.; Salehi, E.; Nashtaei, M.S.; Khanlarkhani, N.; Khezri, Z.; Majidpoor, J.; Abouzaripour, M.; Habibi, M.; et al. Macrophage polarity in cancer: A review. J. Cell. Biochem. 2018, 120, 2756-2765. [CrossRef]

37. Jalil, A.R.; Andrechak, J.C.; Discher, D.E. Macrophage checkpoint blockade: Results from initial clinical trials, binding analyses, and CD47-SIRP $\alpha$ structure-function. Antib. Ther. 2020, 3, 80-94. [CrossRef]

38. Wanderley, C.W.; Colon, D.F.; Luiz, J.P.M.; Oliveira, F.F.; Viacava, P.R.; Leite, C.A.; Pereira, J.A.; Silva, C.M.; Silva, C.R.; Silva, R.L.; et al. Paclitaxel reduces tumor growth by reprogramming tumor-associated macrophages to an M1- profile in a TLR4-dependent manner. Cancer Res. 2018, 78, 5891-5900. [CrossRef]

39. Guerriero, J.L.; Sotayo, A.; Ponichtera, H.E.; Castrillon, J.A.; Pourzia, A.L.; Schad, S.; Johnson, S.F.; Carrasco, R.D.; Lazo, S.; Bronson, R.T.; et al. Class IIa HDAC inhibition reduces breast tumours and metastases through anti-tumour macrophages. Nature 2017, 543, 428-432. [CrossRef]

40. Ferrantini, M.; Capone, I.; Belardelli, F. Interferon- $\alpha$ and cancer: Mechanisms of action and new perspectives of clinical use. Biochimie 2007, 89, 884-893. [CrossRef] [PubMed]

41. Saleiro, D.; Platanias, L.C. Interferon signaling in cancer. Non-canonical pathways and control of intracellular immune checkpoints. Semin. Immunol. 2019, 43, 101299. [CrossRef]

42. Platanias, L.C. Mechanisms of type-I- and type-II-interferon-mediated signalling. Nat. Rev. Immunol. 2005, 5, 375-386. [CrossRef]

43. Hemmati, S.; Haque, T.; Gritsman, K. Inflammatory Signaling Pathways in Preleukemic and Leukemic Stem Cells. Front. Oncol. 2017, 7, 265. [CrossRef]

44. Neumann, H.A.; Fauser, A.A. Effect of interferon on pluripotent hemopoietic progenitors (CFU-GEMM) derived from human bone marrow. Exp. Hematol. 1982, 10, 587-590.

45. Hehlmann, R.; Heimpel, H.; Hasford, J.; Kolb, H.J.; Pralle, H.; Hossfeld, D.K.; Queisser, W.; Löffler, H.; Hochhaus, A.; Heinze, B. Randomized comparison of interferon-alpha with busulfan and hydroxyurea in chronic myelogenous leukemia. The German CML Study Group. Blood 1994, 84, 4064-4077. [CrossRef]

46. Tura, S.; Baccarani, M.; Zuffa, E.; Russo, D.; Fanin, R.; Zaccaria, A.; Fiacchini, M. Interferon Alfa-2a as Compared with Conventional Chemotherapy for the Treatment of Chronic Myeloid Leukemia. N. Engl. J. Med. 1994, 330, 820-825. 
47. Ohnishi, K.; Ohno, R.; Tomonaga, M.; Kamada, N.; Onozawa, K.; Kuramoto, A.; Dohy, H.; Mizoguchi, H.; Miyawaki, S.; Tsubaki, K. A randomized trial comparing interferon-alpha with busulfan for newly diagnosed chronic myelogenous leukemia in chronic phase. Blood 1995, 86, 906-916. [CrossRef]

48. Selleri, C.; Sato, T.; Del Vecchio, L.; Luciano, L.; Barrett, A.J.; Rotoli, B.; Young, N.S.; Maciejewski, J.P. Involvement of Fas-Mediated Apoptosis in the Inhibitory Effects of Interferon- $\alpha$ in Chronic Myelogenous Leukemia. Blood 1997, 89, 957-964. [CrossRef]

49. Kreutzman, A.; Rohon, P.; Faber, E.; Indrák, K.; Juvonen, V.; Kairisto, V.; Voglova, J.; Sinisalo, M.; Flochová, E.; Vakkila, J.; et al. Chronic Myeloid Leukemia Patients in Prolonged Remission following Interferon- $\alpha$ Monotherapy Have Distinct Cytokine and Oligoclonal Lymphocyte Profile. PLoS ONE 2011, 6, e23022. [CrossRef]

50. Rohon, P. Biological therapy and the immune system in patients with chronic myeloid leukemia. Int. J. Hematol. 2012, 96, 1-9. [CrossRef]

51. Berger, U.; Engelich, G.; Reiter, A.; Hochhaus, A.; Hehlmann, R. Imatinib and beyond? The new CML study IV. Ann. Hematol. 2004, 83, 258-264. [CrossRef]

52. Preudhomme, C.; Guilhot, J.; Nicolini, F.E.; Guerci-Bresler, A.; Rigal-Huguet, F.; Maloisel, F.; Coiteux, V.; Gardembas, M.; Berthou, C.; Vekhoff, A.; et al. Imatinib plus Peginterferon Alfa-2a in Chronic Myeloid Leukemia. N. Engl. J. Med. 2010, 363, 2511-2521. [CrossRef]

53. Talpaz, M.; Mercer, J.; Hehlmann, R. The interferon-alpha revival in CML. Ann. Hematol. 2015, 94, 195-207. [CrossRef]

54. Guilhot, F.; Rigal-Huguet, F.; Guilhot, J.; Guerci-Bresler, A.-P.; Maloisel, F.; Rea, D.; Coiteux, V.; Gardembas, M.; Berthou, C.; Vekhoff, A.; et al. Long-term outcome of imatinib $400 \mathrm{mg}$ compared to imatinib $600 \mathrm{mg}$ or imatinib $400 \mathrm{mg}$ daily in combination with cytarabine or pegylated interferon alpha 2a for chronic myeloid leukaemia: Results from the French SPIRIT phase III randomised trial. Leukemia 2021, 35, 2332-2345. [CrossRef]

55. Burchert, A.; Saussele, S.; Eigendorff, E.; Müller, M.C.; Sohlbach, K.; Inselmann, S.; Schütz, C.; Metzelder, S.K.; Ziermann, J.; Kostrewa, P.; et al. Interferon alpha 2 maintenance therapy may enable high rates of treatment discontinuation in chronic myeloid leukemia. Leukemia 2015, 29, 1331-1335. [CrossRef]

56. Mu, H.; Zhu, X.; Jia, H.; Zhou, L.; Liu, H. Combination Therapies in Chronic Myeloid Leukemia for Potential Treatment-Free Remission: Focus on Leukemia Stem Cells and Immune Modulation. Front. Oncol. 2021, 11, 643382. [CrossRef]

57. Gerds, A.; Gotlib, J. NCCN Guidelines Version 2.2021: Myeloproliferative Neoplasms. 2021. Available online: https:/ / www.nccn. org/professionals/physician_gls/pdf/cml.pdf (accessed on 8 September 2021).

58. Kiladjian, J.-J.; Cassinat, B.; Chevret, S.; Turlure, P.; Cambier, N.; Roussel, M.; Bellucci, S.; Grandchamp, B.; Chomienne, C.; Fenaux, P. Pegylated interferon-alfa-2a induces complete hematologic and molecular responses with low toxicity in polycythemia vera. Blood 2008, 112, 3065-3072. [CrossRef]

59. Jabbour, E.; Kantarjian, H.; Cortes, J.; Thomas, D.; Garcia-Manero, G.; Ferrajoli, A.; Faderl, S.; Richie, M.A.; Beran, M.; Giles, F.; et al. PEG-IFN- $\alpha$-2b therapy in BCR-ABL-negative myeloproliferative disorders. Cancer 2007, 110, 2012-2018. [CrossRef]

60. Quintás-Cardama, A.; Kantarjian, H.; Manshouri, T.; Luthra, R.; Estrov, Z.; Pierce, S.; Richie, M.A.; Borthakur, G.; Konopleva, M.; Cortes, J.; et al. Pegylated Interferon Alfa-2a Yields High Rates of Hematologic and Molecular Response in Patients With Advanced Essential Thrombocythemia and Polycythemia Vera. J. Clin. Oncol. 2009, 27, 5418-5424. [CrossRef]

61. Parmeggiani, L.; Ferrant, A.; Rodhain, J.; Michaux, J.L.; Sokal, G. Alpha interferon in the treatment of symptomatic myelofibrosis with myeloid metaplasia. Eur. J. Haematol. 2009, 39, 228-232. [CrossRef]

62. Silver, R.T.; Vandris, K.; Goldman, J.J. Recombinant interferon- $\alpha$ may retard progression of early primary myelofibrosis: A preliminary report. Blood 2011, 117, 6669-6672. [CrossRef]

63. Ianotto, J.-C.; Boyer-Perrard, F.; Gyan, E.; Laribi, K.; Cony-Makhoul, P.; Demory, J.-L.; De Renzis, B.; Dosquet, C.; Rey, J.; Roy, L.; et al. Efficacy and safety of pegylated-interferon $\alpha$-2a in myelofibrosis: A study by the FIM and GEM French cooperative groups. Br. J. Haematol. 2013, 162, 783-791. [CrossRef]

64. Kim, M.; Hwang, S.; Park, K.; Kim, S.Y.; Lee, Y.K.; Lee, D.S. Increased Expression of Interferon Signaling Genes in the Bone Marrow Microenvironment of Myelodysplastic Syndromes. PLoS ONE 2015, 10, e0120602. [CrossRef]

65. Pellagatti, A.; Cazzola, M.; Giagounidis, A.; Perry, J.; Malcovati, L.; Della Porta, M.G.; Jädersten, M.; Killick, S.; Verma, A.; Norbury, C.J.; et al. Deregulated gene expression pathways in myelodysplastic syndrome hematopoietic stem cells. Leukemia 2010, 24, 756-764. [CrossRef]

66. Kitagawa, M.; Saito, I.; Kuwata, T.; Yoshida, S.; Yamaguchi, S.; Takahashi, M.; Tanizawa, T.; Kamiyama, R.; Hirokawa, K. Overexpression of tumor necrosis factor (TNF)- $\alpha$ and interferon (IFN)- $\gamma$ by bone marrow cells from patients with myelodysplastic syndromes. Leukemia 1997, 11, 2049-2054. [CrossRef]

67. Tettamanti, S.; Pievani, A.; Biondi, A.; Dotti, G.; Serafini, M. Catch me if you can: How AML and its niche escape immunotherapy. Leukemia 2021, 1-10. [CrossRef]

68. Mo, X.; Wang, Y.; Zhang, X.; Xu, L.; Yan, C.; Chen, H.; Chen, Y.; Qin, Y.; Liu, K.; Huang, X. Interferon- $\alpha$ Is Effective for Treatment of Minimal Residual Disease in Patients with $t(8 ; 21)$ Acute Myeloid Leukemia After Allogeneic Hematopoietic Stem Cell Transplantation: Results of a Prospective Registry Study. Oncologist 2018, 23, 1349-1357. [CrossRef] [PubMed]

69. Jiang, H.; Liu, X.-H.; Kong, J.; Wang, J.; Jia, J.-S.; Lu, S.-Y.; Gong, L.-Z.; Zhao, X.-S.; Jiang, Q.; Chang, Y.-J.; et al. Interferon- $\alpha$ as maintenance therapy can significantly reduce relapse in patients with favorable-risk acute myeloid leukemia. Leuk. Lymphoma 2021, 1-8. [CrossRef] 
70. Zhu, Y.; An, X.; Zhang, X.; Qiao, Y.; Zheng, T.; Li, X. STING: A master regulator in the cancer-immunity cycle. Mol. Cancer 2019, 18, 152. [CrossRef] [PubMed]

71. Curran, E.; Chen, X.; Corrales, L.; Kline, D.E.; Dubensky, T.W.; Duttagupta, P.; Kortylewski, M.; Kline, J. STING Pathway Activation Stimulates Potent Immunity against Acute Myeloid Leukemia. Cell Rep. 2016, 15, 2357-2366. [CrossRef]

72. Yum, S.; Li, M.; Frankel, A.E.; Chen, Z.J. Roles of the cGAS-STING Pathway in Cancer Immunosurveillance and Immunotherapy. Annu. Rev. Cancer Biol. 2019, 3, 323-344. [CrossRef]

73. Flood, B.A.; Higgs, E.; Li, S.; Luke, J.J.; Gajewski, T.F. STING pathway agonism as a cancer therapeutic. Immunol. Rev. 2019, 290, 24-38. [CrossRef] [PubMed]

74. SSallman, D.; Asch, A.S.; Al Malki, M.M.; Lee, D.J.; Donnellan, W.B.; Marcucci, G.; Kambhampati, S.; Daver, N.G.; Garcia-Manero, G.; Komrokji, R.S.; et al. The First-in-Class Anti-CD47 Antibody Magrolimab (5F9) in Combination with Azacitidine Is Effective in MDS and AML Patients: Ongoing Phase 1b Results. Blood 2019, 134, 569. [CrossRef]

75. Chung, S.S.; Eng, W.S.; Hu, W.; Khalaj, M.; Garrett-Bakelman, F.E.; Tavakkoli, M.; Levine, R.L.; Carroll, M.; Klimek, V.M.; Melnick, A.M.; et al. CD99 is a therapeutic target on disease stem cells in myeloid malignancies. Sci. Transl. Med. 2017, 9, eaaj2025. [CrossRef] [PubMed]

76. Vaikari, V.P.; Du, Y.; Wu, S.; Zhang, T.; Metzeler, K.; Batcha, A.M.N.; Herold, T.; Hiddemann, W.; Akhtari, M.; Alachkar, H. Clinical and preclinical characterization of CD99 isoforms in acute myeloid leukemia. Haematologica 2019, 105, 999-1012. [CrossRef]

77. Naik, J.; Themeli, M.; de Jong-Korlaar, R.; Ruiter, R.W.; Poddighe, P.J.; Yuan, H.; De Bruijn, J.D.; Ossenkoppele, G.J.; Zweegman, S.; Smit, L.; et al. CD38 as a therapeutic target for adult acute myeloid leukemia and T-cell acute lymphoblastic leukemia. Haematologica 2018, 104, e100-e103. [CrossRef]

78. Dos Santos, C.; Xiaochuan, S.; Chenghui, Z.; Habineza Ndikuyeze, G.; Glover, J.; Secreto, T.; Doshi, P.; Sasser, K.; Danet-Desnoyers, G. Anti-Leukemic Activity of Daratumumab in Acute Myeloid Leukemia Cells and Patient-Derived Xenografts. Blood 2014, 124, 2312. [CrossRef]

79. Hellmich, C.; Mistry, J.J.; Lambert, A.; Moore, J.A.; Jibril, A.; Collins, A.; Bowles, K.M.; Rushworth, S.A. Abstract 1048: Targeting BCL-2 and CD38 in models of acute myeloid leukemia reduces tumour burden. Cancer Res. 2021, 81, 1048.

80. Stirewalt, D.L.; Radich, J.P. The role of FLT3 in haematopoietic malignancies. Nat. Rev. Cancer 2003, 3, 650-665. [CrossRef]

81. Heitmann, J.S.; Dörfel, D.; Kayser, S.; Heuser, M.; Thol, F.; Kapp-Schwoerer, S.; Bethge, W.; Grosse-Hovest, L.; Steiner, M.; Märklin, M.; et al. First-in-Human Phase I Dose Escalation and Expansion Study Evaluating the Fc Optimized FLT3 Antibody Flysyn in Acute Myeloid Leukemia Patients with Minimal Residual Disease. Blood 2020, 136, 8-9. [CrossRef]

82. Sanford, D.; Blum, W.G.; Ravandi, F.; Klisovic, R.B.; Borthakur, G.; Walker, A.R.; Garcia-Manero, G.; Marcucci, G.; Wierda, W.G.; Whitman, S.P.; et al. Efficacy and safety of an anti-FLT3 antibody (LY3012218) in patients with relapsed acute myeloid leukemia. J. Clin. Oncol. 2015, 33, 7059. [CrossRef]

83. Bianchi, M.E.; Mezzapelle, R. The Chemokine Receptor CXCR4 in Cell Proliferation and Tissue Regeneration. Front. Immunol. 2020, 11, 2109. [CrossRef]

84. Becker, P.S.; Foran, J.M.; Altman, J.K.; Yacoub, M.A.; Castro, J.E.; Sabbatini, P.; Dilea, C.; Wade, M.; Xing, G.; Gutierrez, A.; et al. Targeting the CXCR4 Pathway: Safety, Tolerability and Clinical Activity of Ulocuplumab (BMS-936564), an Anti-CXCR4 Antibody, in Relapsed/Refractory Acute Myeloid Leukemia. Blood 2014, 124, 386. [CrossRef]

85. Bajaj, J.; Konuma, T.; Lytle, N.K.; Kwon, H.Y.; Ablack, J.N.; Cantor, J.M.; Rizzieri, D.; Chuah, C.; Oehler, V.G.; Broome, E.H.; et al. CD98-Mediated Adhesive Signaling Enables the Establishment and Propagation of Acute Myelogenous Leukemia. Cancer Cell 2016, 30, 792-805. [CrossRef]

86. Bixby, D.; Wieduwilt, M.J.; Akard, L.P.; Khoury, H.J.; Becker, P.S.; Van Der Horst, E.H.; Ho, W.; Cortes, J.E. A Phase I Study of IGN523, a Novel Anti-CD98 Monoclonal Antibody in Patients with Relapsed or Refractory Acute Myeloid Leukemia (AML). Blood 2015, 126, 3809. [CrossRef]

87. Fathi, A.T. Antibody-Based Therapy in AML: Antibody-Drug Conjugates and Bispecific Agents. Clin. Lymphoma Myeloma Leuk. 2021, 21, S112-S113. [CrossRef]

88. Baeuerle, P.A.; Reinhardt, C. Bispecific T-Cell Engaging Antibodies for Cancer Therapy: Figure 1. Cancer Res. 2009, 69, 4941-4944. [CrossRef]

89. Zhu, M.; Wu, B.; Brandl, C.; Johnson, J.; Wolf, A.; Chow, A.; Doshi, S. Blinatumomab, a Bispecific T-cell Engager (BiTE $\left.{ }^{\circledR}\right)$ for CD-19 Targeted Cancer Immunotherapy: Clinical Pharmacology and Its Implications. Clin. Pharmacokinet. 2016, 55, 1271-1288. [CrossRef]

90. Ravandi, F.; Walter, R.B.; Subklewe, M.; Buecklein, V.; Jongen-Lavrencic, M.; Paschka, P.; Ossenkoppele, G.J.; Kantarjian, H.M.; Hindoyan, A.; Agarwal, S.K.; et al. Updated results from phase I dose-escalation study of AMG 330, a bispecific T-cell engager molecule, in patients with relapsed/refractory acute myeloid leukemia (R/R AML). J. Clin. Oncol. 2020, 38, 7508. [CrossRef]

91. Subklewe, M.; Stein, A.; Walter, R.B.; Bhatia, R.; Wei, A.H.; Ritchie, D.; Bücklein, V.; Vachhani, P.; Dai, T.; Ravandi, F.; et al. Antreas Hindoyanet al. Preliminary Results from a Phase 1 First-in-Human Study of AMG 673, a Novel Half-Life Extended (HLE) Anti-CD33/CD3 BiTE ${ }^{\circledR}$ (Bispecific T-Cell Engager) in Patients with Relapsed/Refractory (R/R) Acute Myeloid Leukemia (AML). Blood 2019, 134, 833. [CrossRef] 
92. Ravandi, F.; Bashey, A.; Stock, W.; Foran, J.M.; Mawad, R.; Egan, D.; Blum, W.; Yang, A.; Pastore, A.; Johnson, C.; et al. Complete Responses in Relapsed/Refractory Acute Myeloid Leukemia (AML) Patients on a Weekly Dosing Schedule of Vibecotamab (XmAb14045), a CD123 x CD3 T Cell-Engaging Bispecific Antibody; Initial Results of a Phase 1 Study. Blood 2020, 136, 4-5. [CrossRef]

93. Montesinos, P.; Roboz, G.J.; Bulabois, C.-E.; Subklewe, M.; Platzbecker, U.; Ofran, Y.; Papayannidis, C.; Wierzbowska, A.; Shin, H.J.; Doronin, V.; et al. Safety and efficacy of talacotuzumab plus decitabine or decitabine alone in patients with acute myeloid leukemia not eligible for chemotherapy: Results from a multicenter, randomized, phase 2/3 study. Leukemia 2020, 35, 62-74. [CrossRef]

94. Uy, G.L.; Aldoss, I.; Foster, M.C.; Sayre, P.H.; Wieduwilt, M.J.; Advani, A.S.; Godwin, J.E.; Arellano, M.L.; Sweet, K.L.; Emadi, A.; et al. Flotetuzumab as salvage immunotherapy for refractory acute myeloid leukemia. Blood J. Am. Soc. Hematol. 2021, $137,751-762$.

95. Yeung, Y.A.; Krishnamoorthy, V.; Dettling, D.; Sommer, C.; Poulsen, K.; Ni, I.; Pham, A.; Chen, W.; Liao-Chan, S.; Lindquist, K.; et al. An Optimized Full-Length FLT3/CD3 Bispecific Antibody Demonstrates Potent Anti-leukemia Activity and Reversible Hematological Toxicity. Mol. Ther. 2020, 28, 889-900. [CrossRef]

96. Brauchle, B.; Goldstein, R.L.; Karbowski, C.M.; Henn, A.; Li, C.-M.; Bücklein, V.L.; Krupka, C.; Boyle, M.C.; Koppikar, P.; Haubner, S.; et al. Characterization of a Novel FLT3 BiTE Molecule for the Treatment of Acute Myeloid Leukemia. Mol. Cancer Ther. 2020, 19, 1875-1888. [CrossRef]

97. Mu-Mosley, H.; Ostermann, L.B.; Zhao, R.; Bonifant, C.L.; Gottschalk, S.; Velasquez, M.P.; Andreeff, M. Venetoclax Enhances Anti-Leukemia Activity of CD123-Specific BiTE-Secreting T-Cells in AML. Blood 2020, 136, 12-13. [CrossRef]

98. Stein, E.M.; Tallman, M.S. Emerging therapeutic drugs for AML. Blood J. Am. Soc. Hematol. 2016, 127, 71-78. [CrossRef] [PubMed]

99. Chalouni, C.; Doll, S. Fate of antibody-drug conjugates in cancer cells. J. Exp. Clin. Cancer Res. 2018, 37, 1-12. [CrossRef]

100. Fenton, C.; Perry, C.M. Gemtuzumab Ozogamicin. Drugs 2005, 65, 2405-2427. [CrossRef]

101. Sievers, E.; Larson, R.; Stadtmauer, E.A.; Estey, E.; Löwenberg, B.; Dombret, H.; Karanes, C.; Theobald, M.; Bennett, J.M.; Sherman, M.L.; et al. Efficacy and Safety of Gemtuzumab Ozogamicin in Patients With CD33-Positive Acute Myeloid Leukemia in First Relapse. J. Clin. Oncol. 2001, 19, 3244-3254. [CrossRef] [PubMed]

102. Ricart, A.D. Antibody-Drug Conjugates of Calicheamicin Derivative: Gemtuzumab Ozogamicin and Inotuzumab Ozogamicin Clin. Cancer Res. 2011, 17, 6417-6427. [CrossRef] [PubMed]

103. Godwin, C.D.; Gale, R.P.; Walter, R.B. Gemtuzumab ozogamicin in acute myeloid leukemia. Leukemia 2017, 31, 1855-1868. [CrossRef]

104. Castaigne, S.; Pautas, C.; Terré, C.; Raffoux, E.; Bordessoule, D.; Bastie, J.-N.; Legrand, O.; Thomas, X.; Turlure, P.; Reman, O.; et al. Effect of gemtuzumab ozogamicin on survival of adult patients with de-novo acute myeloid leukaemia (ALFA-0701): A randomised, open-label, phase 3 study. Lancet 2012, 379, 1508-1516. [CrossRef]

105. Atallah, E.; Berger, M.; Jurcic, J.; Roboz, G.; Tse, W.; Mawad, R.; Rizzieri, D.; Begna, K.; Orozco, J.; Craig, M.; et al. A phase 2 study of actinium-225 (225Ac)-lintuzumab in older patients with untreated acute myeloid leukemia (AML). J. Med. Imaging Radiat. Sci. 2019, 50, S37. [CrossRef]

106. Stein, E.M.; Walter, R.B.; Erba, H.P.; Fathi, A.T.; Advani, A.S.; Lancet, J.E.; Ravandi, F.; Kovacsovics, T.; DeAngelo, D.; Bixby, D.; et al. A phase 1 trial of vadastuximab talirine as monotherapy in patients with CD33-positive acute myeloid leukemia. Blood 2018, 131, 387-396. [CrossRef]

107. Fathi, A.T.; Erba, H.P.; Lancet, J.E.; Stein, E.M.; Ravandi, F.; Faderl, S.; Walter, R.B.; Advani, A.S.; DeAngelo, D.; Kovacsovics, T.J.; et al. A phase 1 trial of vadastuximab talirine combined with hypomethylating agents in patients with CD33-positive AML. Blood 2018, 132, 1125-1133. [CrossRef]

108. Testa, U.; Pelosi, E.; Castelli, G. CD123 as a Therapeutic Target in the Treatment of Hematological Malignancies. Cancers 2019, 11, 1358. [CrossRef]

109. Daver, N.G.; Montesinos, P.; DeAngelo, D.J.; Wang, E.S.; Papadantonakis, N.; Deconinck, E.; Erba, H.P.; Pemmaraju, N.; Lane, A.A.; Rizzieri, D.A.; et al. Clinical Profile of IMGN632, a Novel CD123-Targeting Antibody-Drug Conjugate (ADC), in Patients with Relapsed/Refractory (R/R) Acute Myeloid Leukemia (AML) or Blastic Plasmacytoid Dendritic Cell Neoplasm (BPDCN). Blood 2019, 134, 734. [CrossRef]

110. Snyder, J.T.; Malinao, M.-C.; Dugal-Tessier, J.; Atkinson, J.E.; Anand, B.S.; Okada, A.; Mendelsohn, B.A. Metabolism of an Oxime-Linked Antibody Drug Conjugate, AGS62P1, and Characterization of Its Identified Metabolite. Mol. Pharm. 2018, 15, 2384-2390. [CrossRef] [PubMed]

111. Rudra-Ganguly, N.; Lowe, C.; Virata, C.; Leavitt, M.; Jin, L.; Mendelsohn, B.; Snyder, J.; Aviña, H.; Zhang, C.; Russell, D.L.; et al. AGS62P1, a Novel Anti-FLT3 Antibody Drug Conjugate, Employing Site Specific Conjugation, Demonstrates Preclinical Anti-Tumor Efficacy in AML Tumor and Patient Derived Xenografts. Blood 2015, 126, 3806. [CrossRef]

112. Gyurkocza, B.; Nath, R.; Stiff, P.J.; Agura, E.; Litzow, M.R.; Tomlinsonm, B.; Choe, H.; Abhyankar, S.; Litzow, M.R.; Tomlinson, B.; et al. Targeted Conditioning with Anti-CD45 Iodine (131I) Apamistamab [Iomab-B] Leads to High Rates of Allogeneic Transplantation and Successful Engraftment in Older Patients with Active, Relapsed or Refractory (rel/ref) AML after Failure of Chemotherapy and Targeted Agents: Preliminary Midpoint Results from the Prospective, Randomized Phase 3 Sierra Trial. Biol. Blood Marrow Transpl. 2020, 26, S32-S33. 
113. Bartlett, N.L.; Herrera, A.F.; Domingo-Domenech, E.; Mehta, A.; Forero-Torres, A.; Garcia-Sanz, R.; Armand, P.; Devata, S.; Izquierdo, A.R.; Lossos, I.S.; et al. A phase $1 \mathrm{~b}$ study of AFM13 in combination with pembrolizumab in patients with relapsed or refractory Hodgkin lymphoma. Blood 2020, 136, 2401-2409. [CrossRef]

114. Boddu, P.; Kantarjian, H.; Garcia-Manero, G.; Allison, J.; Sharma, P.; Daver, N. The emerging role of immune checkpoint based approaches in AML and MDS. Leuk. Lymphoma 2017, 59, 790-802. [CrossRef]

115. Daver, N.; Basu, S.; Garcia-Manero, G.; Cortes, J.E.; Ravandi, F.; Jabbour, E.J.; Hendrickson, S.; Pierce, S.; Ning, J.; Konopleva, M.; et al. Phase IB/II Study of Nivolumab in Combination with Azacytidine (AZA) in Patients (pts) with Relapsed Acute Myeloid Leukemia (AML). Blood 2016, 128, 763. [CrossRef]

116. Davids, M.S.; Kim, H.T.; Bachireddy, P.; Costello, C.; Liguori, R.; Savell, A.; Lukez, A.P.; Avigan, D.; Chen, Y.-B.; McSweeney, P.; et al. Ipilimumab for Patients with Relapse after Allogeneic Transplantation. N. Engl. J. Med. 2016, 375, 143-153. [CrossRef] [PubMed]

117. Zeidan, A.M.; Knaus, H.A.; Robinson, T.M.; Towlerton, A.M.; Warren, E.; Zeidner, J.; Blackford, A.L.; Duffield, A.S.; Rizzieri, D.; Frattini, M.G.; et al. A Multi-center Phase I Trial of Ipilimumab in Patients with Myelodysplastic Syndromes following Hypomethylating Agent Failure. Clin. Cancer Res. 2018, 24, 3519-3527. [CrossRef] [PubMed]

118. Mikkilineni, L.; Kochenderfer, J.N. Chimeric antigen receptor T-cell therapies for multiple myeloma. Blood J. Am. Soc. Hematol. 2017, 130, 2594-2602. [CrossRef] [PubMed]

119. Maude, S.L.; Laetsch, T.W.; Buechner, J.; Rives, S.; Boyer, M.; Bittencourt, H.; Bader, P.; Verneris, M.R.; Stefanski, H.E.; Myers, G.D.; et al. Tisagenlecleucel in Children and Young Adults with B-Cell Lymphoblastic Leukemia. N. Engl. J. Med. 2018, 378, 439-448. [CrossRef]

120. Liu, Y.; Bewersdorf, J.P.; Stahl, M.; Zeidan, A.M. Immunotherapy in acute myeloid leukemia and myelodysplastic syndromes: The dawn of a new era? Blood Rev. 2019, 34, 67-83. [CrossRef]

121. Gill, S.I. How close are we to CAR T-cell therapy for AML? Best Pract. Res. Clin. Haematol. 2019, 32, 101104. [CrossRef]

122. Tettamanti, S.; Biondi, A.; Biagi, E.; Bonnet, D. CD123 AML targeting by chimeric antigen receptors: A novel magic bullet for AML therapeutics? Oncoimmunology 2014, 3, e28835. [CrossRef]

123. Michelozzi, I.; Kirtsios, E.; Giustacchini, A. Driving CAR T Stem Cell Targeting in Acute Myeloid Leukemia: The Roads to Success Cancers 2021, 13, 2816. [CrossRef] [PubMed]

124. Harris, K.; LaBelle, J.L.; Bishop, M.R. Current Status of CAR T Cell Therapy for Leukemias. Curr. Treat. Options Oncol. 2021, 22, 1-17. [CrossRef]

125. Cummins, K.D.; Gill, S. Chimeric antigen receptor T-cell therapy for acute myeloid leukemia: How close to reality? Haematologica 2019, 104, 1302. [CrossRef]

126. Albinger, N.; Hartmann, J.; Ullrich, E. Current status and perspective of CAR-T and CAR-NK cell therapy trials in Germany. Gene Ther. 2021, 28, 513-527. [CrossRef] [PubMed]

127. Kerbauy, L.N.; Ang, S.; Liu, E.; Banerjee, P.P.; Wu, Y.; Shaim, H.; Lim, F.L.W.I.; Basar, R.; Li, L.; Muftuoglu, M.; et al. Cord Blood NK Cells Engineered to Express a Humanized CD123-Targeted Chimeric Antigen Receptor (CAR) and IL-15 As Off-the-Shelf Therapy for Acute Myeloid Leukemia. Blood 2017, 130, 4453.

128. Tang, X.; Yang, L.; Li, Z.; Nalin, A.P.; Dai, H.; Xu, T.; Jia, Y.; You, F.; Zhu, M.; Shen, W.; et al. First-in-man clinical trial of CAR NK-92 cells: Safety test of CD33-CAR NK-92 cells in patients with relapsed and refractory acute myeloid leukemia. Am. J. Cancer Res. 2018, 8, 1083. 